\title{
First Canadian Urban Forestry Conference Held in Winnipeg
}

\author{
by J.H. Cayford, R.P.F.
}

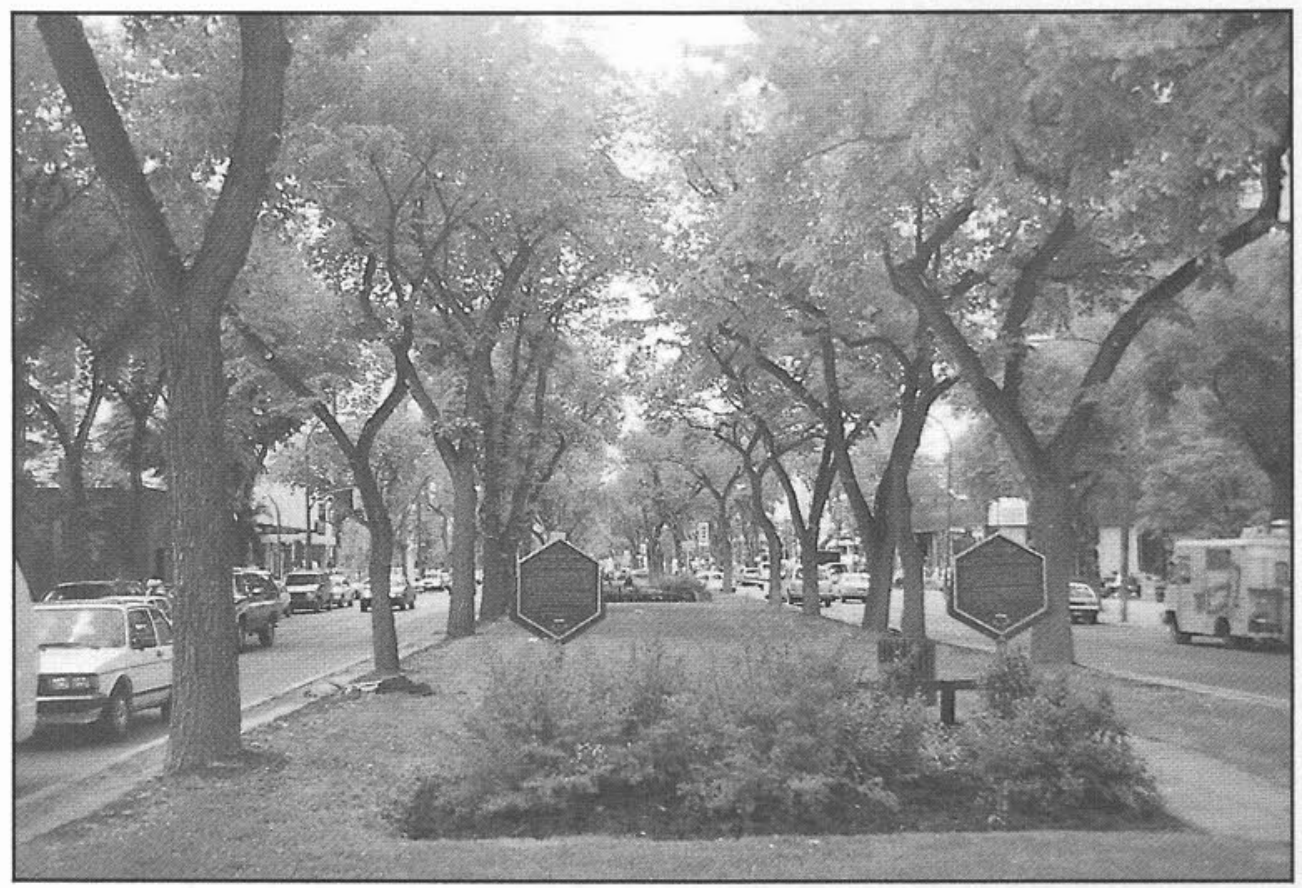

Winnipeg - city of trees

A major landmark in Canadian urban forestry occurred in Winnipeg, May 31-June 2, 1993, when the First Canadian Urban Forests Conference was held. The conference with the theme "New Directions" was sponsored by the Canadian Forestry Association (CFA) and Tree Plan Canada, with the assistance of the City of Winnipeg Parks and Recreation Department, Manitoba Forestry Association, Manitoba Department of Natural Resources and Forestry Canada. The International Society of Arboriculture, the Canadian Society of Landscape Architects and the Urban Forestry Working Group, Canadian Institute of Forestry participated in the national steering committee for the conference. The meeting attracted about 300 delegates and guests representing municipal planners, forest managers, residential associations, tree nursery owners, arborists, parks staff, educators, professional foresters and community groups. There was representation from all Canadian provinces.
The three-day meeting included halfday opening and closing plenary sessions, concurrent sessions for three half days and a half day of field trips. In addition, there was an evening round table on Dutch elm disease, which was open to the public, two luncheons, one with the Honourable Gary Filmon, Premier of Manitoba and the other with Jean-Claude Mercier, Deputy Minister, Forestry Canada, as speakers, and a closing banquet with Prof. Tim Bell, Professor of Climatology, University of Winnipeg, as speaker.

The first plenary was opened by John Hreno, President, Canadian Forestry Association and Acting General Manager, Parks and Recreation Department, City of Winnipeg. Mr. Hreno emphasized the growing importance of urban forests and trees in view of global concerns about the environment. He noted the particular importance of tree cover in the Canadian plains and noted that Winnipeg was celebrating the 100th anniversary of its Parks and Recreation Department. Mayor Susan Thompson of the City of Winnipeg welcomed delegates to Winnipeg and explained that the city had 60,000 elms, had instituted a Dutch elm disease control program in 1978 and had kept the losses to less than 2 per cent annually. She also indicated that she intended to pursue a "Winnipeg evergreen" program.

The keynote speaker was Frederick J. Deneke, Assistant Director, Cooperative Forestry, Urban and Community Forestry, US Forest Service, who spoke on the topic "Urban Forestry in North America: Towards a Global Ecosystem Perspective". The speaker defined urban forestry as "the sustained planning, planting, protection, maintenance, and care of trees, forests, greenspace and related resources in and around cities and communities for economic, environmental, social, and public health benefits to people". In his speech, Mr. Deneke discussed the importance of urban trees, reviewed the history of urban forestry in North America, observed that just as we are coming to more fully understand the 


\section{Urban Forestry in North America}

Urban and community forestry of the future must embrace the concept of "integrated ecosystem management" and provide a framework for its application at the city/community level. Management must respond to people and their positive actions because they are critical to the proper functioning of the urban ecosystem. In short, it is time for city arborists and foresters to begin doing urban forestry with people.

Urban and community forestry of the future must incorporate a new entrepreneurial approach that provides the opportunity for people to plan, build, and operate the place of their dreams, without draining government and societal resources.

Urban forestry of the future can be a means for helping to address the root causes of social ills such as vandalism, crime, community decline, disenfranchisement and loss of hope by young and old. It can facilitate healing of community spirit through shared planning and sweat equity of people creating their own sustainable urban environment.

Increased attention in urban forestry research will have to be given to understanding and documenting the wide range of individual, social, and community benefits provided by urban forests and greenspace. It will also be necessary to develop better knowledge on how to manage urban forests to increase these same benefits.

Citizen interest and action will require that technical assistance efforts expand beyond the traditional tree planting, tree care, inventories and management plans working with municipal arborists and urban foresters.

Increasing emphasis will be needed in the areas of organizing, educating, training, and providing technical support to volunteer groups; partnership and coalition building; fund raising; and the fostering of self-sustaining local governmental and volunteer community forestry programs.

Remember, earlier I talked about our present approach being one where all the parts are treated separately. This is the old Newtonian science model in which the parts make up the whole. Through integrated ecosystem management of our urban forests, we begin the "quantum" approach recognizing that the whole is in every part. People all over the world are seeking meaning and mission. Urban forestry is a natural outlet for this expression. Combining this emerging energy with a new "quantum" approach in urban forestry, makes for an exciting future!

\section{Extracts from Summary of Keynote Address by} Frederick J. Deneke benefits of the urban forest, funding is being reduced as cities make hard financial choices, and outlined the trend of urban forestry away from an individual tree horticultural approach towards an ecosystem approach. Extracts from the summary of the paper are in the box.

Following the keynote address, Dorothy Dobbie, Member of Parliament for Winnipeg South, discussed the federal role in forestry; John Fisher, Chairman, National Community Tree Foundation, spoke on community-based urban forestry; and Erik Jorgensen, consulting forester, Arbor Consultants, Inc., Guelph, Ontario, and often considered the father of urban forestry in Canada, discussed the history of urban forestry in Canada. Ms. Dobbie, in discussing the federal role, made reference to research programs in Dutch elm disease and gypsy moth, the forest insect and disease survey and to the recently introduced Tree Plan Canada program through which 325 million trees are to be planted over a five-year period. In his address, John Fisher reviewed the importance of trees in absorbing carbon and suggested that Tree Plan Canada will play a significant role in this regard. He also emphasized that the program suggests a Canadian commitment to the future and to environmental protection. Prof. Jorgensen discussed early Canadian urban forestry initiatives including the establishment of the Shade Tree Research Laboratory at the University of Toronto and an urban forestry program established by Forestry Canada at the Forest Management Institute.

The concurrent sessions featured (1) community action in the urban forest, (2) tree care research, (3) new directions in the urban forest, (4) community action in an urban forest, (5) planning and design in the urban forest and (6) education, training and the tree ethic. Each session featured about six speakers; in two instances, panel discussions were featured. Comments on some of the presentations are presented in the box.

The final plenary session included a presentation on The Global ReLeaf Program of the American Forests organization by Gary Moll, Vice President for Urban Forestry, American Forests, Washington, DC, plus a summary panel with delegate interaction which focussed on both urban forestry and the organization of the conference. Major trends in urban forestry currently include the movement towards a wholistic, ecosystem approach to managing urban forests and parklands, increasing emphasis on the use of native species, a move from manicured landscaping to more natural environments, a focus on community action, on partnerships, and on public participation.

There were three well-organized field trips. The first visited one of Winnipeg's oldest parks - Kildonan, drove along the historic Red River, and visited Oak Hammock Marsh, a prairie marsh oasis known for its abundant bird life. The second visited Assiniboine Park, Winnipeg's largest urban park, Assiniboine Forest and the Fort Whyte Centre, the city's environmental education centre converted from clay pits dug by a cement company. The third trip visited three tree nurseries and the Island Park Arboretum at Portage la Prairie.

The conference was a great success. It was well-organized with the program committee selection of speakers and topics very good. The logistics committee under the chairmanship of Diane Beaven, Manitoba Forestry Association, is to be commended for its efforts. 


\section{A Delegate Comments on Selected Papers}

Updated Tree Planting Techniques in the Landscape Ian Bruce, Professor of Forestry, Humber College. Among other things, he stressed the importance of selecting trees to match the hardiness zones and space available at the planting locations. He also indicated that pruning the crowns of trees to compensate for roots broken off in lifting at the nursery was unnecessary.

Round Table on Dutch Elm Disease - Richard Westwood, Chief, Forest Protection, Forestry Branch, Manitoba Natural Resources. Dr. Westwood gave an excellent overview of the programs developed both in the Province of Manitoba and the City of Winnipeg since the mid-1970's.

Regulation of Trees on Private Property - Alan Slater Duncan, Senior Landscape Architect, City of Vancouver, British Columbia. This well illustrated presentation demonstrated the judicious removal of trees from overcrowded lots and from situations where they were likely to obstruct a desirable view from a neighbouring property.

Urban Tree Inventory Maintenance Program - Stephen King, Superintendent of Parks and Grounds, City of Halifax, Nova Scotia. Not only did this presentation introduce us to the many different tree species used in the landscaping of Halifax, but it also indicated the usefulness of GIS (Geographic Information System) in keeping track of individual tree problems.

\section{Municipal Urban Forestry and the Role of Public Tree} Commissions - Don Murray, Forester, City of Fredericton; Alex Dickson, UNB Professor of Forestry and Chairman of the Fredericton Tree Commission. It was pointed out that successful control of Dutch Elm Disease in Fredericton was due in large measure to these two factors: the make up of the Tree Commission (volunteers with some appropriate expertise) and a sanitation program aided and abetted by a City by-law which authorized City workers to enter private property, with or without the owners' permission, to remove diseased trees or branches.

Following field trips to nature reserves on the afternoon of the second day, participants enjoyed a hearty roast beef dinner in the rustic setting of the Hitch'n Post Country Barbecue Restaurant in the village of Grosse Isle north of Winnipeg. The informal dinner speaker on this occasion was Dr. J. James Kielbaso, Professor of Urban Forestry at Michigan State University. His entertaining talk was entitled Trees Need Love Too. Reaching back into ancient history and mythology, he discussed love and trees separately and then brought them together in this day and age. He managed to introduce humour along with enlightenment.
The Rotary Heritage Forest was the subject of a presentation by Rotarian Clive Justice of British Columbia. Using high-quality slides and videos, he showed how 39 classes of grade 5 students planted trees (including tubes and fertilizer) twice a day for two months earlier this year. The planting site, he pointed out, was within sight of 100,000 vehicles a day travelling along a nearby highway. This project proved to be very effective in terms of conservation education.

Ecoethics in an Urban Ecosystem - Dr. Paul Aird, University of Toronto professor of forestry. Using slides and overheads, Dr. Aird discussed some of the unsightliness and lack of care in the city landscape. He pointed out that it was important for the general citizenry to show concern and responsibility as well as the urban authorities with regard to the appearance of the city landscape.

Urban Trees and Forest Education Training Program a panel presentation by Jon Williams, Petawawa National Forestry Institute (Focus on Forests): Allan Foster, Kortright Centre, Maple, Ontario (Folklore and Story Telling Approaches to Environmental Education): and Sandy Hyman, social worker and acting deputy mayor, City of Winnipeg (Municipal Action on Dutch Elm Disease Control Through Job Development Training and Education). Several interesting points were brought out by the panel: while half of Canada is forested, 75 per cent of the people live in urban areas; thinking skills, particularly in science and mathematics, among school students need to be improved; in order to keep children in schools, the curriculum has to be relevant to the students' perceived needs; foresters, too, need to develop critical thinking skills; these thinking skills can be developed through the use of role playing; forestry has become the meeting place of such social sciences as sociology, social psychology, etc.; stories can greatly assist in the retention of "nature study" facts whereas the presentation of unadorned information is quickly forgotten; providing employment in the control of Dutch Elm Disease via apprenticeship training of welfare recipients can save municipalities money.

Urban Forests and Global Warming - Dr. Tim Ball, Professor of Climatology, University of Winnipeg. In this after-dinner presentation, Dr. Ball challenged and poked fun at the prophets of climatological doom. Some of the disturbing predictions of recent times, he pointed out, lacked solid scientific evidence.

Alex Dickson, Faculty of Forestry, University of New Brunswick 


\section{Reflections on the First Canadian Urban Forestry Conference}

The overall reaction to the First Urban Forestry Conference is very positive. There were many interesting topics and many good speakers. It would be difficult to separate the best from the worst for all were good and all presented some aspect or aspects of the urban forestry picture which belonged there. (I liked Professor Erik Jorgensen's reminiscing and Allan Foster's story telling best but it was all worth hearing.) The field trips were well received. The dinner for all at the Hitchin' Post outside Winnipeg was a great success. The luncheons and banquets were handled with class yet an informality that made them fun and interesting to attend. The facilities were fine though too expensive for many. Overall the organization of the event was well done. There seemed to be lots of people with jobs to do in making the conference run smoothly and for the most part that was done.

Certainly, the program was unique in that instead of the usual crying and name calling heard at many environmental events this one found people of common interests looking positively towards finding solutions. Not only were they looking to solutions but they were looking to developing them themselves rather than pointing the finger at someone else and saying "that's their job".

On the matter of numbers it was interesting that about half the people were from Manitoba and about seventy percent came from Manitoba and the west. Only 20 per cent of the attendees were from Ontario and roughly 5 per cent from Quebec. Every province was represented by at least one attendee and South Dakota, Alaska and Washington, DC also had delegates. Total attendance was over 260 .

There were about ten commercial exhibits and five from non-profit groups. These all added to the educational value of the total program.

There were probably too many public servants in proportion to the volunteers but they certainly did not overshadow the good works or enthusiasm of the volunteers. In many cases the praise of the volunteer efforts by the paid employees

\author{
by Jim Coats, R.P.F. \\ Executive Vice-President \\ Ontario Forestry Association/ \\ Trees Ontario
}

urban forestry the boost that it so richly deserves. The volunteer groups that did take part are but a fraction of those that exist and another conference could provide an opportunity for more of them to tell their stories.

As so often happens at conferences there were sessions going on in two separate places at the same time. While that offers extra opportunities for the attendees it also leaves the feeling that you have missed a lot of sessions you would like to have attended.

If one was critical of the program they might suggest there was a preponderance of material on the Dutch elm disease problem compared to other urban forestry topics but a trip through the streets of Winnipeg soon indicated the importance, and the success, of the Elm Guard programs there.

And hopefully there will be another conference in the not too distant future. The Canadian Forestry Association and the National Community Tree Foundation deserve great praise for undertaking the urban forestry conference in Winnipeg. They were helped immensely by a number of bodies including the Manitoba Forestry Association, the City of Winnipeg, Forestry Canada

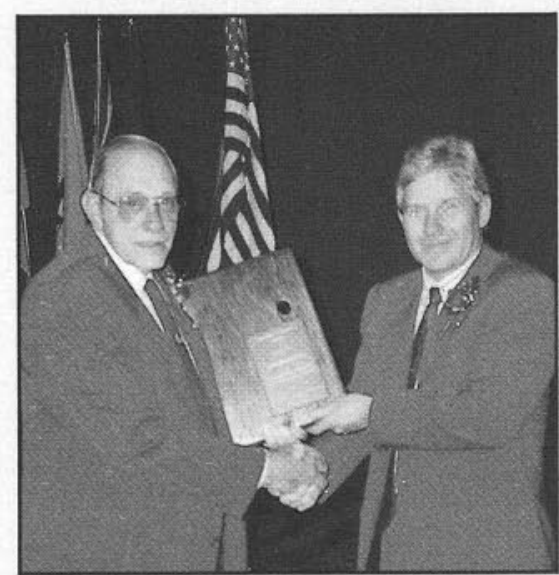

John Hreno, President, CFA (r) presents Trees for Tomorrow Award to Professor Erik Jorgensen, Arbor Consultants Inc., Guelph, Ontario. (Photo credit: Manitoba Forestry Association.)

was just what was needed. Their presence also helped to swell the numbers and give and Manitoba Natural Resources. The Canadian Institute of Forestry, International Society of Arboriculture and the Canadian Society of Landscape Architects were also represented on the Steering Committee. All deserve commendation as do the people at the nurseries, parks, interpretive centres and other facilities included in the tours.

There is no doubt that urban residents have a lot to say about forestry and a positive urban forestry program can be a stepping stone to better understanding of forestry across the country. It did this old forester's heart good to hear urbanites talking about the importance of tree protection and tree replacement in a manner that would befit any professional foresters' meetings. It's a long road to public understanding but the first urban forestry conference in Winnipeg was a great stretch of road along the way. 